\title{
A geografia como poética \\ da existência na obra de Gabrielle Roy
}

Maria Bernadette Porto

Recebido em 08 jul 2012 - Aprovado em 18 set 2012

\begin{abstract}
Resumo
A partir de pistas de leitura fornecidas por Michel Onfray (2009), François Ricard (2000 e 2001), François Paré (1992, 2003 e 2007), Jean Morency (2006 e 2009) e Milton Santos (2000), pretende-se refletir sobre a cartografia da afetividade no imaginário de Gabrielle Roy. A ideia norteadora dessas reflexões é mostrar como a consciência de pertencimento a um espaço habitado está estreitamente ligada ao sentimento do existir na poética royana. Para melhor entrar em contato com o sentido do ato de se localizar, a autora explorou, como sugere François Ricard (2001), a experiência da "estrangeiridade" e dos deslocamentos, o que the deu acesso à descoberta da distância e da alteridade.
\end{abstract}

Palavras-chave: imaginário do lugar; travessias identitárias; proximidade e distância. 
A geografia serve primeiro para elaborar uma poética da existência. (...) Uma existência, no momento da morte, se reduz a um conjunto de traços num mapa apergaminhado. (ONFRAY, 2009, p.89)

(...) o papel do lugar é determinante. Ele não é apenas um quadro de vida, mas um espaço vivido, isto é, de experiência sempre renovada, o que permite, ao mesmo tempo, a reavaliação das heranças e a indagação sobre o presente e o futuro (SANTOS, 2000, p.114)

Representativa do conceito de itinerância, proposto por François Paré (2003), a obra de Gabrielle Roy coloca na cena da escrita imagens da errância no espaço canadense, no interior do qual se sobressaiu, desde sua infância, a figura do estrangeiro, o que atribui a essa autora profundamente ligada à "visão cosmopolita da experiência canadense-francesa"1 (MORENCY, 2009, p.152) o papel de precursora avant la lettre de questões abordadas no âmbito da chamada escrita migrante.

Segundo François Ricard (2001), crítico e autor de um texto clássico sobre a biografia de Gabrielle Roy (2000), graças à sua qualidade de estrangeira em relação à realidade quebequense, após um exílio voluntário na Europa, essa escritora nascida em 1909 na província anglófona do Manitoba, decidiu não regressar à terra familiar para se isolar em Montreal. Em função da distância assumida em relação a seu lugar de origem, adotou um olhar diferenciado capaz de lhe assegurar um papel fundamental no âmbito do campo literário quebequense, conferindo-lhe novo rumo. $\mathrm{Na}$ leitura de François Ricard, exilada não apenas geograficamente, mas também do ponto de vista intelectual, no Quebec entre 40 e 45, Roy optou por se manter à margem, preservando sua independência e originalidade em relação às tendências adotadas por autores de sua época. (RICARD, 2001, p.19). "Estrangeira e familiar, distante e tão próxima, diferente e, ao mesmo tempo, semelhante" (RICARD, 2001, p.23), a autora ocupa uma posição à primeira vista paradoxal em relação ao seu local de origem. Curiosamente, como pensa Ricard, o movimento do exílio a conduziu ao retorno a seu ponto de partida, já que em seus escritos revisitava suas paisagens afetivas que, apesar da distância, continuavam a habitá-la. Por ser a escritura uma atividade de estrangeiro (RICARD, 2001, p.31), Roy deixa sua origem para escrever, mas volta a ela através do processo criativo.

Aos olhos de François Ricard, é muito significativo que a opção da autora pela escrita coincida com a ruptura com o Manitoba e com a separação de seu meio familiar, representado por Saint-Boniface, pequena cidade onde nasceu. Para o crítico, Saint-Boniface representaria "a vida tranquila, a ordem, a prote-

1 As traduções são de minha autoria. ção, a troca estreita entre os seres", em oposição ao espaço da exterioridade, ligado ao "perigo e à dispersão." "De um lado, a 
estabilidade e a permanência, do outro, o perigo, os riscos do desaparecimento." (RICARD, 2001, p.27). Núcleo francófono no interior de uma província anglófona, Saint-Boniface pode ser visto como lugar da exiguidade e da resistência, tal como pensa François Paré em seu livro Les littératures de l'exiguité (1992), no qual a noção de exiguidade sugere, não necessariamente limites geográficos, mas a noção de fragilidade e a ameaça de apagamento vividas por comunidades minoritárias que lutam para não deixar apagar sua diferença em contextos de opressão. É o que aparece no capítulo de abertura do tex to de cunho autobiográfico da escritora, intitulado La détresse et l'enchantement (1984): trata-se da reconstituição de uma cena habitual do passado, a travessia da ponte Provencher, feita a pé, pela narradora e sua mãe, que saíam de sua cidadezinha francófona para fazerem compras em Winnipeg, capital anglófona da província do Manitoba. Construído a partir de três momentos, o texto em questão revela: o percurso de ida, alimentado pelos sonhos de aquisição de mercadorias, sempre incompatíveis com as reais possibilidades econômicas da mãe; a chegada à cidade hostil de Winnipeg e ao centro comercial onde nem sempre era possível contar com o acolhimento afável por parte de vendedores; e o retorno a Saint-Boniface, marcado pelo alívio das personagens ao reconhecerem os sinais de seu mundo francófono (a presença da religião católica na paisagem urbana e da língua francesa que mãe e filha mal ousavam falar em Winnipeg). Sinônimo do trânsito entre o familiar e o estrangeiro, entre o mundo da segurança e o da hostilidade, entre duas línguas e duas comunidades em confronto, tal deslocamento corriqueiro não só levou a narradora a constatar a inferiorização de que eram alvo os francófonos em seu próprio país, como também a se deparar com a relativização: como ela percebe, se todos eram estrangeiros, não havia mais estrangeiros. Como afirma Sherry Simon, nessa obra, Roy “designa a travessia de uma ponte como uma viagem iniciática, um despertar que definirá a consciência no centro de sua escritura" (SIMON, 2008, p.236), uma vez que, segundo a própria escritora, tal experiência lhe abria os olhos, estimulava sua imaginação, levava-a a observar. (ROY, 1984, p.11).

Um signo espacial se faz revelador nesse capítulo de $L a$ détresse et l'enchantement: a ponte. Muito mais do que um meio de passagem (SIMON, 2008, p.223), a ponte se insere na poética urbana, sugerindo, em especial no caso de Montreal de hoje, cidade cosmopolita por excelência, as relações multiculturais e a prática da tradução. Para se ler o texto em questão, que remete a outra época e a um espaço marcado pela dualidade, no qual a ponte remete à dicotomia francófonos/anglófonos, pode ser buscado apoio em Jean-Pierre Vernant. Segundo ele,

Atravessar uma ponte, um rio, transpor uma fronteira é deixar o espaço íntimo e familiar onde se está em seu lugar para 
2 Segundo François Ricard, na época de Roy, em Saint-Boniface, laços estreitos uniam seus habitantes como se formassem uma única família. Trazendo na memória seu passado de nômades, apegavam-se ao desejo de enraizamento, desconfiando do espaço da exterioridade. (RICARD, 2001, p.27) Como será visto aqui, a narrativa da viagem dos avós maternos da autora, que deixaram o Quebec para se instalarem no Manitoba, é revisitada em muitos textos da autora.

3 Em Fragiles lumières de la terre. Écrits divers 1942/1970, Gabrielle Roy consagra dois textos à província onde nasceu: "Le Manitoba" e "Mon héritage du Manitoba" (ROY, 1996).

4 Segundo François Ricard, em sua biografia da autora, mais do que as pessoas ou os fatos, os lugares e as paisagens de sua infância marcaram profundamente Gabrielle Roy. Pelo fato de terem sido descritos, repensados e percorridos pela imaginação, eles constituem "uma espécie de geografia interior cujas significações a romancista não deixará nunca de explorar." (RICARD, 2000, p.47) Quanto à Rue Deschambault - rua que, aos olhos da autora, era um universo -, $\mathrm{Ri}^{-}$ card retoma uma frase de Roy: "Será que ela me fez à sua imagem ou fui eu que a fiz à minha?" (RICARD, 2000, p.47), na qual se esboçam as relações estreitas entre ela e a rua de sua infância.

5 Como ocorre com Gabrielle Roy, para Michel Tremblay, a vastidão da exterioridade se faz presente em uma simples rua. Ligada à nostalgia de um lugar distante, planícies sem começo e sem fim habitam a Rue Fabre: graças às histórias que sua mãe lhe contava sobre a província de Saskatchewan onde ela passara anos felizes de sua infância, o menino Michel, vive, penetrar num horizonte diferente, um espaço estrangeiro, desconhecido, em que se arrisca, confrontado com o que é diferente, a se descobrir sem lugar próprio, sem identidade. (VERNANT, 2009, p.197)

À luz do mesmo autor, a passagem da interioridade à exterioridade - que se faz presente no texto citado de Gabrielle Roy - evoca as figuras míticas de Héstia e Hermes, divindades distintas e complementares. Mais uma vez, as palavras de Vernant se revelam significativas:

Para que haja verdadeiramente um interior, ainda é preciso que ele se abra para o exterior a fim de recebê-lo no seu seio. E cada indivíduo humano deve assumir sua parte de Héstia e sua parte de Hermes. Para sermos nós mesmos, é preciso projetar-nos para o que é estrangeiro, prolongar-nos em e para ele. Permanecer fechado em sua identidade é perder-se e deixar de ser. Conhecemo-nos, construímo-nos pelo contato, a troca, o comércio com o outro. Entre as margens do mesmo e do outro, o homem é uma ponte. (VERNANT, 2009, p.198)

No conjunto da obra da autora, as lembranças de Héstia e Hermes se presentificam na vida de personagens femininas que, segundo o título expressivo de um ensaio de Lori Saint-Martin (2002), se situam entre a condição de prisioneiras e a de viajantes, o que aponta para a oposição sedentarismo e nomadismo. Retornando à análise proposta por François Ricard no capítulo "Étrangère et proche" (2001), cabe lembrar que, na poética de Roy, por mais que Saint-Boniface ${ }^{2}$ represente o espaço da proteção e da insularidade, não deixa de sugerir à escritora o apelo da exterioridade. Em textos consagrados ao Manitoba, ${ }^{3}$ Gabrielle Roy realça o encantamento dos vastos espaços - em particular as planícies sem fim -, convite aos deslocamentos e à experiência dos limites.

Não é, pois, por acaso que Gabrielle Roy constitui uma referência obrigatória para dois escritores vinculados ao imaginário do Canadá francês: Jacques Poulin e Michel Tremblay que, em vários de seus textos, dão hospitalidade à autora ou a alguns de seus escritos. Um traço em comum aproxima livros desses três grandes autores: a poética da afetividade, ligada a lugares de memória: a rua (aqui é possível evocar a Rue Deschambault ${ }^{4}$ e a Rue Fabre, ${ }^{5}$ no caso de Roy e Tremblay, respectivamente), a cidade (Quebec para Poulin, Montreal para Tremblay e Roy) e a estrada (a route para Roy e Poulin e o chemin de fer para Roy e para Tremblay, no livro La traversée $d u$ continent), que permitem a alguns de seus personagens descobrir a dimensão maior de seu lugar identitário. Trata-se de reconhecer, como pensa Jean Morency, uma "americanidade ligada à experiência tangível do continente (...) visto como um espaço plenamente habitado, rico de múltiplas possibilidades e marcado por inúmeras redes de sociabilidade" (MORENCY, 2009, p.149). Na sua leitura de romancistas ligados ao Canadá francês, Morency admite que, mesmo após o advento 
da Revolução Tranquila, que provocou grandes mudanças no processo de identificação coletiva, a identidade canadense francesa "conseguiu sobreviver mesmo combatida, recalcada e negada." (MORENCY, 2009, p.148) Para ele, o surgimento da identidade quebequense não apagou, portanto, a experiência canadense francesa, associada à aprendizagem do gesto de habitar a distância na vastidão territorial.

Para Jean Morency, o escritor quebequense que recebeu maior influência de Gabrielle Roy é Jacques Poulin. Autor profundamente ligado à biblioteca afetiva e intelectual, que transporta em suas memórias e em seus textos, Poulin presta homenagem a Roy em alguns de seus romances. Leitor sensível da obra royana, Poulin - que possivelmente se sentiu acolhido em muitas páginas dessa autora - confere-lhe hospitalidade no romance Les yeux bleus de Mistassini (2002), através da figura misteriosa da personagem Gabrielle. Nessa mesma obra, afetado por uma crise de inspiração, a personagem do escritor se apropria de uma frase do romance $L a$ Route d'Altamont de Gabrielle Roy, embaralhando os limites entre seu texto e o de Roy. (POULIN, 2002, p.164) Aí se confirma o sentido da hospitalidade para Derrida, para quem receber é também ser recebido (1997). É ainda sob o signo reversível da hospitalidade que deve ser lido o romance La traduction est une histoire d'amour (2006) de Jacques Poulin, que hospeda muitos escritores, obras e referências livrescas. No romance citado, centrado na experiência afetiva entre um escritor e sua tradutora, e na atividade da tradução - que nos lembra a imagem do albergue do longínquo de Antoine Berman - Poulin alberga nos capítulos de sua obra escritores próximos e distantes, como Hemingway, Saint-Exupéry, Anne Hébert e a própria Gabrielle Roy. Uma referência en passant a uma das novelas do livro Cet été qui chantait de Roy se revela de modo discreto no mesmo romance (POULIN, 2006, p.124) que retoma o episódio da déportation des ouaouarons e a alusão a Monsieur Toung criado por Roy (ROY, 1993 a, p.11).

Explorando um pouco mais o romance La traduction est une histoire d'amour, cabe lembrar que, associado a uma prática do lugar, o tema da hospitalidade - também caro a Gabrielle Roy, em particular na novela "Un vagabond frappe à notre porte" (1994) -, é recorrente em todo o livro de Poulin. As personagens do escritor e de sua tradutora - que evocam as relações entre Kafka e Milena, através de um jogo intertextual visto como acolhimento - hospedam gatos e uma garota abandonada. A obra sugere, em vários momentos, que amar e traduzir supõem o ato de acolher o outro que, por sua vez, retribui o mesmo gesto, assegurando a reversibilidade afetiva. A própria definição do gênero romanesco

Continuação nota 5 por procuração, a saudade de um espaço de afetividade (TREMBLAY, 1996). proposta pela personagem do escritor, a partir de uma citação de Heidegger ("Le langage est la maison de l'être") é lida a partir do sentido de hospedar. Inspirando-se em uma afirmação de Sylvie Durastanti, citada como fonte bibliográfica no fim do livro, o 
escritor Waterman vê o romance como uma casa construída com material do passado (cinzas mortas) e o do futuro (pólen fecundo). Tirando partido da associação feita por ele entre casa, abrigo e refúgio, sua jovem tradutora recorre ao dicionário para aí buscar o significado do vocábulo refúgio. Definido pelo Petit Robert como: "pequena construção no alto de uma montanha, onde os alpinistas podem passar a noite", a tradutora reconhece que aí se encontra a melhor definição de romance. (POULIN, 2006, p.88). Nessa passagem metalinguística, identifica-se a escritura como lugar de habitabilidade por excelência, o que pode ser estendido à atividade tradutória e à prática da leitura. Sob esse aspecto, basta lembrar a "caverna mágica", reinvenção do velho sofá da sala, feita pelo menino Michel Tremblay que, com três almofadas, construía um abrigo no qual ele se sentia seguro, mesmo quando lia histórias apavorantes. (TREMBLAY, 1994, p.87). Quanto a Gabrielle Roy, a habitabilidade da escritura é ressaltada por François Ricard ao abordar a aparente contradição da autora, que, como já foi ressaltado, se exila para melhor encontrar seu lugar no mundo, justamente na sua atividade de escritora. Aproximando o escritor da personagem do vagabundo (“Un vagabond frappe à notre porte, 1994), Ricard acredita que, assim como a existência do vagabundo alterna errância e vida familiar, Roy soube aliar a partida ao retorno." (RICARD, 2001, p.39) Nesse sentido, mesmo afastando-se, ela consegue manter o contato com sua "casa" identitária: "ela parte para escrever, mas volta escrevendo" (RICARD, 2001, p.32).

Estudos desenvolvidos na área da geopoética podem iluminar a leitura de obras literárias, revisitadas pelo olhar de quem se coloca entre a geografia e a literatura. É o que se destaca no último parágrafo do artigo "Topographier pour comprendre l'espace romanesque" de Rachel Bouvet. Como se dialogasse com o que acaba de ser ressaltado no parágrafo anterior a respeito da habitabilidade associada à literatura, Bouvet afirma:

O desejo de construir e de habitar uma caverna surge na infância, ao mesmo tempo em que se desenvolve a faculdade de se mergulhar inteiramente nos volumes feitos de papel. Se o primeiro tende a desaparecer na idade adulta, em compensação, os romances podem se tornar verdadeiras moradas imaginárias cujos cantos e recônditos tem-se prazer de revisitar (...). (BOUVET, 2011, p.91).

No que diz respeito às afinidades eletivas entre Gabrielle Roy e Michel Tremblay, cabe salientar o impacto provocado no escritor ao ler Bonheur d'occasion, o que é retratado em sua obra Un ange cornu avec des ailes de tôle (1994), na qual relata suas experiências inaugurais como leitor. Segundo ele, pela primeira vez em sua vida reconhecia seu país em uma obra da literatura quebequense. Mas é sobretudo por influência de sua mãe, grande apaixonada pelas planícies do oeste canadense, como Gabrielle 
Roy, que Tremblay se identificou com a poética da existência elaborada nas obras dessa autora. Em outras palavras, o circuito dialógico estabelecido entre Roy e os escritores citados, confere a seus textos uma rede de vozes da afetividade que se respondem de perto, iluminando-se uns aos outros, apontando para uma existência fundamentada nas promessas de um mundo mais ético e humano. Na rede intertextual criada entre obras de Roy, Poulin e Tremblay ressalta-se a importância de configurações espaciais privilegiadas, nas quais os escritores buscam inspiração em seu repertório ficcional.

Em muitos momentos de sua vasta e rica obra, Gabrielle Roy mostra que, desde cedo, o sentimento do existir esteve ligado à consciência espacial. Para a autora, a ligação com o país passa, necessariamente, por uma paisagem: "O primeiro vínculo de um país não seria um vínculo físico, rio, riacho, atalho, estrada, ferrovia? Isto explicaria porque nosso coração tem uma ligação com a ferrovia, ao passo que ele se liga pouco ao avião, magnífico pássaro sem pátria" (ROY, 1988, p.102). A importância das viagens de trem no imaginário royano se confirma no texto de cunho autobiográfico Le temps qui m'a manqué (2000) no qual a autora associa, na abertura de sua narrativa, os trilhos à felicidade: "Os espaços imensos, a partida, o trem, a viagem, e no fim, a felicidade, me pareceram, durante anos, indissoluvelmente ligados" (ROY, 2000, p.13). Todavia, no livro citado, revestido do signo do luto, a viagem de trem adquire outro sentido, uma vez que é o percurso em direção ao enterro da mãe da autora: "Eu escutava os trilhos. Eles me diziam que era uma infelicidade infinita ter vindo ao mundo." (ROY, 2000, p.39). Assim, vinculadas a experiências de vida e de morte, paisagens descortinadas na imobilidade ou nos deslocamentos tornam-se espaços existenciais, ligados à história da escritora que os elege como referenciais significativos.

Em alguns dos textos royanos, uma paisagem em particular confere a razão de ser para certos personagens, justificando seu estar no mundo. É o caso das colinas para a mãe de Éveline (1988), que, ao longo de toda a vida, guardou a lembrança das colinas do Quebec, província de onde saíra um dia para viver no Manitoba. Segundo sua filha Éveline, provavelmente, na véspera de sua morte, de todas as paisagens vistas durante sua existência, uma, em particular, lhe teria vindo à memória: a lembrança das colinas quebequenses, cujo contorno "lhe voltou à memória, na véspera de sua morte, como sua imagem da verdade do mundo" (ROY, 1988, p.41). Tal passagem dialoga com a epígrafe de Michel Onfray citada na abertura dessas reflexões: na véspera de sua morte, a personagem royana traz no "mapa apergaminhado" de sua memória um elemento espacial que traduzia o significado de toda sua vida.

Para um maior aprofundamento da análise da cartografia da afetividade no universo royano, impõem-se certas considerações 
sobre a noção de paisagem. Não se confundindo com uma morfologia do meio-ambiente, o estudo da paisagem deve levar em conta a subjetividade do observador. Isso confirma as palavras do geógrafo e orientalista Augustin Berque para quem "a paisagem não existe fora de nós assim como não existimos fora de nossa paisagem. Por isso, falar da paisagem é sempre um pouco uma autoreferência" (BERQUE, 1994, p.27). Na poética royana, além de seu valor afetivo ligado ao gesto de apropriação simbólica, a paisagem se reveste de um sentido estético, o que nos remete à leitura proposta pelo filósofo Alain Roger. Segundo ele, só é possível passar do país à paisagem pela mediação da arte, "uma mediação lenta, difusa, complexa, frequentemente difícil de reconstituir, mas sempre indispensável" (ROGER, 1994, p.120) Isso porque, segundo o mesmo filósofo, o país equivale ao grau zero da paisagem e precede o processo de transformação em arte de algo que existe como um vir a ser no domínio estético (ROGER, 1994, p.116).

A lembrança das colinas do Quebec atravessa também páginas do romance $L a$ route d'Altamont, no qual, enquanto palimpsesto, em um jogo de ocultamento e revelação, a memória do passado - representada por esse acidente geográfico - se aloja sob a superfície da experiência vivida no presente. Para a personagem da mãe, reencontrar, ao lado da filha, as colinas fugidias da estrada de Altamont a levava a se aproximar das colinas de sua infância, situadas na longínqua província francófona canadense, e da menina que fora um dia, que ficara nos distantes sítios do passado. A possibilidade de resgatar uma paisagem querida do outrora se manifesta como ressignificação de um elemento topográfico do presente que deixa de ser o que é para se tornar aquilo que representa no mapa da memória dos sentimentos.

Também na novela "Où iras-tu Sam Lee Wong?" (Un jardin au bout du monde, 1994), texto centrado na vivência espacial, o prestígio das colinas se destaca em vários momentos da narrativa. Primeiramente, deve ser ressaltado o papel relevante de Roy na representação da alteridade oriental, muito antes da recente presença de autores e personagens oriundos do Oriente no campo literário quebequense, no interior do qual, como pensa Simon Harel (2009), deixam a posição de seres vistos - até como objeto de curiosidade e de exotismo - para assumirem o lugar daquele que vê.

Na novela em questão, o protagonista assume a decisão de emigrar, movido pela necessidade de sair de um país excessivamente povoado que só lhe oferecia para dormir um buraco no muro. Cansado de ser apenas mais um rosto amarelo no seio de uma infinidade de rostos amarelos, experimentava, em sua própria pátria, a dificuldade de assumir sua subjetividade. Seu desejo de partir está, portanto, vinculado ao de encontrar um lugar no mundo, onde construiria para si - ainda que de modo precário 
e provisório - um teto todo seu sob o qual abrigaria sua diferença. Â luz de estudos desenvolvidos por Abdelmalek Sayad, sabe-se que "a dimensão econômica da condição do imigrante é sempre o elemento que determina todos os outros aspectos do estatuto do imigrante" (SAYAD, 1998, p.63), estrangeiro cuja estadia em um país depende do mercado de trabalho. Tal relação é tão estreita, segundo Sayad, que é possível afirmar que

Foi o trabalho que fez "nascer" o imigrante, que o fez existir; é ele, quando termina, que faz "morrer" o imigrante, que decreta sua negação ou que o empurra para o não-ser. E esse trabalho, que condiciona toda a existência do imigrante, não é qualquer trabalho, não se encontra em qualquer lugar; ele é o trabalho que o "mercado de trabalho para imigrantes" lhe atribui e no lugar em que lhe é atribuído: trabalhos para imigrantes que requerem, pois, imigrantes; imigrantes para o trabalho que se tornam, dessa forma, trabalhos para imigrantes. (SAYAD, 1998, p.55)

Tais considerações encontram eco na novela citada na qual aparecem duas faces do trabalhador chinês no Canadá: dono de restaurante ou proprietário de lavanderia. (ROY, 1994, p.51). Em Vancouver, na época da imigração do personagem, se a cidadezinha era suficientemente importante para receber um chinês, ele teria um restaurante. À medida que prosperava, essa mesma pequena cidade poderia receber um segundo chinês cujo trabalho já estava definido por antecipação: ele seria tintureiro.

Não foi por acaso que, assim que chegou ao Canadá, ajudado pela Sociedade de Ajuda aos Filhos do Oriente, ao consultar o mapa, no momento de escolher a cidadezinha na qual iria se instalar, optou por Horizonte, pois aí reconheceu a presença de colinas. Na verdade, como diz o texto, ele procurava as colinas dificilmente alcançáveis no fundo de suas lembranças. Somente elas "conseguiam conservar em si mesmo uma espécie de identidade e o sentimento de que, projetado no Canadá, ele era ainda um pouco Sam Lee Wong." (ROY, 1994, p.52) Já no navio que o levara ao novo país, a imagem das colinas de seu passado na China o acompanhou de perto. Muitos anos mais tarde, com a chegada do progresso à cidade onde vivia, contratempos inesperados o levam a tomar a decisão de voltar para seu país. No momento em que se preparava para partir, uma festa de despedida é organizada em sua homenagem por habitantes da cidade, que nunca pareceram se importar com ele, que também se dá conta de que ninguém mais o esperava na China. Imbuído da necessidade de recomeçar, apoiando-se em sua capacidade de resistência, resolve mudar para outra cidade do oeste canadense. Por uma estranha coincidência, também aí as colinas fazem sua aparição epifânica: ao se deslocar na direção oposta à de Horizonte, redescobre, maravilhado, as mesmas colinas do lado oposto ao da cidade onde vivera durante anos. Como eixo do mundo a partir do qual 
sua existência se organizara, a imagem das colinas aponta para a memória-palimpsesto dos afetos. As palavras finais da novela sugerem a possibilidade de se reinventar a origem e as promessas da apropriação de um novo lugar que dialoga com o de seu passado no país natal a partir do embaralhamento das noções de distância e proximidade: "Ele levantou os olhos em direção às colinas. Lá para onde ele sempre conduzira seus passos não devia estar muito longe agora." (ROY, 1994, p.99)

Se a inscrição de paisagens da afetividade se faz presente em muitos personagens royanos, permitindo-lhes habitar, ainda que provisória e oniricamente, momentos de seu passado, o espaço físico pode apontar ainda para as possibilidades de um futuro. Assim, para a personagem Eveline (1988) - que aos setenta e três anos empreende sozinha uma longa viagem de ônibus, percorrendo em seis dias a estrada entre o Manitoba e a Califórnia - a constatação da existência de grandes espaços desconhecidos que pareciam aguardar sua descoberta era a prova de que ela ainda estava viva por ser capaz de conservar sua capacidade desejante e sua disponibilidade para a sempre renovada novidade do mundo: "Era seu amor pelos espaços infinitos, por esses grandes espaços que poderiam ser vistos como inúteis que revivia aqui. Neste momento, ela não se sentia de modo nenhum no fim de sua existência. Ah, não, havia de fato muitas coisas a serem vistas nesse mundo. Como seria possível um dia alguém se sentir velho e sem forças?" (ROY, 1988, p.38)

No mesmo livro, a experiência dos deslocamentos favorece a consciência diaspórica e as trocas multiculturais. Tendo optado por viajar de ônibus, durante cinco dias, para ir ao encontro de seu irmão Majorique que a chamara para junto de si em um telegrama misterioso em que anunciava sua grande partida, Éveline abre uma janela para as relações com a alteridade. Durante todo o trajeto, por sua capacidade fabulativa, seduz todos os passageiros do ônibus, levando-os a revisitarem suas próprias histórias e paisagens afetivas, distantes do continente americano. Por sua vez, grande amante de viagens, Majorique resolvera parar suas andanças, fixando-se na Califórnia em uma grande propriedade, em torno da qual reuniu seus filhos dispersos pelo mundo. Casados com pessoas de outras nacionalidades, formavam o que Majorique designou como a "pequena comunidade de nações". Ao chegar, enfim, à Califórnia, Éveline descobre o verdadeiro sentido da viagem oferecida por seu irmão, que acabara de falecer. Antes de embarcar na " grande partida" anunciada no telegrama enviado à irmã, decidira lhe dar um presente: a possibilidade de viajar e de ter acesso à sua família multicultural. O romance termina com uma bela imagem: a do cortejo fúnebre em direção ao cemitério dos autóctones, situado no alto de uma colina. Ao se deparar com a visão de uma superfície calma, brilhante e infinita, nunca apreendida por seu olhar, Éveline pensa estar diante de 
6 Na verdade, a narradora parece não ter certeza desse parentesco. Todavia, muitos laços de identificação os aproxima: o mesmo sobrenome, a tradição, o modo de falar, objetos biográficos (a mesma imagem da Sagrada Família). uma miragem. Cabe a um de seus sobrinhos-netos, esclarecer o mistério que lhe causara uma emoção indescritível: tratava-se do oceano. Assim se realizou a última das surpresas de Majorique, conhecido por seu humor e pelo hábito de pregar peças em seus familiares. Transformando seu próprio enterro em espetáculo e descoberta para Éveline, ele lhe permite ter uma visão epifânica de uma paisagem que, associada ao infinito e aos deslocamentos, atenua o caráter finito da existência humana e a dor de sua própria perda. Para além da morte, Majorique enriquece o repertório de lembranças geográficas de Éveline, envolvidas pela cumplicidade e amizade.

No texto de cunho autobiográfico Ah!Ély!Ély!Ély, publicado no mesmo livro em que se encontra a história de Éveline, fazendo-se ponte entre dois mundos, a narradora pega um trem e desce, durante a noite escura, no meio do nada, para ir a um vilarejo onde moram parentes distantes que ela não conhecia. ${ }^{6}$ Lá experimenta a ambivalência de uma sensação que mistura impressões de proximidade e de distância, que se traduz como estranhamento diante do que lhe seria familiar, e como apropriação do sentimento de ser canadense: "Essa noite insólita em que desembarquei como estrangeira me tornava familiar e amigável. Será que um dia eu me sentira tanto no Canadá como nessa noite?" (ROY, 1988, p.102). Deve ser ressaltada, no fim do mesmo texto, a felicidade conhecida pela narradora ao se sentir disponível para o movimento: "Meu Deus, como eu estava feliz, em movimento, disponível, aberta ao desconhecido de nosso país como a todo futuro ainda possível do mundo." (1988, p.122). Esse texto ilustra como na poética de Roy o mundo aparece como possibilidade e disponibilidade para o exercício maior da alteridade graças à prática do encontro. Identificamos no geógrafo Milton Santos pistas para a leitura da autora que aposta a tal ponto no entendimento entre os homens para além das diversidades que seus textos se revestem do sentido da promessa. Apontando, no mundo atual - visto como disponibilidade e possibilidade - condições para uma grande mutação capaz de neutralizar os efeitos perversos da globalização, tornando-a mais humana, o autor de Por uma outra globalização: do pensamento único à consciência universal afirma:

Agora que estamos descobrindo o sentido de nossa presença no planeta, pode-se dizer que uma história universal verdadeiramente humana está, finalmente, começando. (SANTOS, 2000, p.174)

Para chegar a essa descoberta, o ato de viajar constituiu uma experiência exemplar e enriquecedora para a escritora, justamente por colocá-la diante da multiplicidade de culturas, o que a levou a uma maior abertura para a alteridade. Em sua infância, ouvia atenta, não só os relatos feitos por seu pai, funcionário do governo responsável pela instalação de imigrantes, como também a narrativa 
Escanaba se refere a uma cidade real, nos Estados Unidos, na qual se instalaram muitas famílias canadenses francesas, mas é também a metáfora do lugar promissor que suscita o desejo dos deslocamentos. da viagem dos avós maternos que deixaram o Quebec para viver no Manitoba. Herança transmitida através das gerações, a busca de um lugar promissor - que levou muitos canadenses franceses a se deslocarem de seu lugar de origem - é vista como o fantasma de Escanaba ${ }^{7}$ por François Paré (2007). Estimulados a sair da exiguidade quebequense (PARÉ, 2007, p.173), que se refere menos à extensão geográfica do que a uma certa concepção imaginária de um povo que, durante séculos, resistiu à assimilação fechando-se em si mesmo, os canadenses franceses souberam responder aos apelos de um outro lugar. No que concerne às personagens femininas de Gabrielle Roy, o desejo de partir - com seus riscos e atrativos - seria uma atualização do mito de Escanaba, sinônimo de desassossego segundo Paré, sugerindo a quebra de interditos e limites emocionais que as confinavam no espaço doméstico. No conjunto da obra royana os charmes do espaço diaspórico se manifestam como "a transmissão de narrativas fundadoras entre gerações" (PARÉ, 2007, p, 50), o que confirma os vínculos entre mobilidades geográficas e mobilidades textuais.

O reconhecimento de seu país como espaço marcado pelos movimentos diaspóricos se explica ainda pelas deambulações feitas por Gabrielle Roy, na sua infância, em companhia da mãe, nos locais onde havia comunidades de imigrantes. Dessa forma, lhe foi possível acompanhar as metamorfoses do espaço habitado - e heterogêneo - no Canadá e reconhecer "a disparidade da espécie humana", acrescida da constatação da semelhança de todos os seres. (ROY, 1996, p.190-191). Mais uma vez pode-se salientar os vínculos entre a viagem e a descoberta do sentido maior da condição humana, como destaca Lori Saint-Martin na sua leitura de Gabrielle Roy:

Viajar é tocar de perto o sentido da existência, a verdade, a essência das coisas. Viaja-se, é claro, para si mesmo, para se ultrapassar, para se descobrir, para se criar, mas também para os outros: para descobri-los, para se dar a eles, para se aproximarem uns e outros nesse vasto território onde todos se sentem tão perdidos. (SAINT-MARTIN, 2006, p. 194)

Ler e viajar através dos textos de Gabrielle Roy é descobrir, com surpresa e emoção sempre renovadas, o acolhimento do mundo, no qual a distância e a proximidade se conjugam, ultrapassando as cartografias dos confrontos e dos hiatos existenciaise culturais. Propondo uma ética da hospitalidade associada a uma geografia da proximidade e à presença das paisagens da memória, Roy não deixa de nos convidar para a descoberta do Outro e da estrangeiridade que nos habita e nos cerca, tornando-nos membros de uma sociedade - talvez utópica - marcada pela compreensão em um mundo ao mesmo tempo familiar e distante, semelhante e heterogêneo. 


\begin{abstract}
From the evidences provided by the reading of Michel Onfray (2009), François Ricard (2000 e 2001), François Paré (1992, 2003 e 2007), Jean Morency (2006 e 2009) and Milton Santos (2000), a reflection upon the cartography of affection in Gabrielle Roy's imaginary is intended. The guiding idea to these reflections is to show how the awareness of belonging to an inhabited space is strictly linked to the feeling of existing in Royan's poetic. To get an enhanced contact with the sense of the act of locating herself, the author explored, as François Ricard (2001) suggests, the experience of foreignness and displacement, which gave her access to the discovery of otherness.
\end{abstract}

Keywords: imaginary place; crossings identity; proximity and distance.

\title{
REFERÊNCIAS
}

BERMAN, Antoine. A tradução e a letra ou o albergue do estrangeiro. 7 Letras/PGET, 2007.

BERQUE, Augustin. Paysage, milieu, histoire. In: BERQUE, Augustin et alii (dir.) Cinq propositions pour une théorie du paysage. Seyssel: Champ Vallon, 1994.

BERQUE, Augustin et alii (dir.) Cinq propositions pour une théorie du paysage. Seyssel: Champ Vallon, 1994.

BOUVET, Rachel. Topographier pour comprendre l'espace romanesque. In: BOUVET, Rachel et CAMUS, Audrey (dir.) Topographies romanesques. Rennes: Presses Universitaires de Rennes: Québec: Presses de l'Université du Québec, 2011.

CERTEAU, Michel de. A invenção do cotidiano I: artes de fazer. Petrópolis: Editora Vozes.

DERRIDA, Jacques e DUFOURMANTELLE, Anne. De l'hospitalité. Paris: Calmann-Lévy, 1997.

HALL, Stuart. Da diáspora: identidades e mediações culturais. Belo Horizonte: Editora da UFMG; Brasília: representação da UNESCO no Brasil, 2003.

HAREL, Simon. Une appartenance orientale. In: PRZYCHODZEN, Janusz (dir.) Asie du soi, Asie de l'autre: récits et figures de l'altérité. Québec: Les presses de l'Université Laval, 2009.

HOTTE, Lucie; POIRIER, Guy (dir.) Habiter la distance: études en marge de la distance habitée. Ottawa: Éditions Prise de parole, 2009. 
MORENCY, Jean; TOONDER, Jeanette den; LINTVELT, Jaap (dir.). Romans de la route et voyages identitaires. Montréal: Boréal, 2006.

MORENCY, Jean. Romanciers du Canada français: Gabrielle Roy, Jacques Poulin, Michel Tremblay, Roch Carrier. In: HOTTE, Lucie; POIRIER, Guy (dir.) Habiter la distance: études en marge de la distance habitée. Ottawa: Éditions Prise de parole, 2009.

ONFRAY, Michel. Teoria da viagem: poética da geografia. Porto Alegre: L\&PM, 2009.

PARÉ, François. Les littératures de l'exiguité. Ottawa: Le Nordir, 1992. . La distance habitée. Ottawa: Le Nordir, 2003.

2007.

. Le fantasme d'Escanaba. Montréal: Éditions Nota Bene,

PORTO, Maria Bernadette. Escritas do exílio: habitar e representar a distância. In: PORTO, Maria Bernadette e VINNA NETO, Arnaldo Rosa. Habitar e representar a distância em textos literários canadenses e brasileiros. Niterói: Editora da UFF, 2012.

POULIN, Jacques. Les yeux bleus de Mistassini. Montréal: Leméac/ Actes Sud, 2002.

2006.

. La traduction est une histoire d'amour. Montréal: Leméac,

RICARD, François. Gabrielle Roy: une vie. Biographie. Montréal: Boréal, 2000.

tréal: Nota Bene, 2001.

Introduction à l'oeuvre de Gabrielle Roy (1945-1975). Mon-

ROGER, Alain. Histoire d'une passion théorique ou Comment on devient un Raboliot du Paysage. In: BERQUE, Augustin et alii (dir.) Cinq propositions pour une théorie du paysage. Seyssel: Champ Vallon, 1994.

ROY, Gabrielle. La détresse et l'enchantement. Montrèal: Boréal, 1984. . De quoi t'ennuies-tu, Éveline? suivi de Ély! Ély! Ély! Récits. Montréal: Boréal, 1988.

Boréal, 1993 a.

Cet été qui chantait. Récits. Nouvelle édition. Montréal:

. La route d'Altamont. Roman. Nouvelle édition. Montréal: Boréal, 1993 b. réal, 1994.

. Un jardin au bout du monde. Nouvelles. Montréal: Bo-

Fragiles lumières sur la terre: écrits divers 1942-1970. Nouvelle édition.Montréal: Boréal, 1996.

. Le temps qui m'a manqué.Suite de La détresse et l'enchantement. Montréal: Boréal, 2000.

SAINT-MARTIN, Lori. La Voyageuse et la prisonnière. Gabrielle Roy et la question des femmes, Montréal, Boréal, 2002. 
Le road book au féminin du XIXe siècle. Le saga d'Éveline de Gabrielle Roy. In: MORENCY, Jean; TOONDER, Jeanette den; LINTVELT, Jaap (dir.). Romans de la route et voyages identitaires. Montréal: Boréal, 2006.

SANTOS, Milton. Por uma outra globalização: do pensamento único à consciência universal. Rio de Janeiro: Record, 2011.

SAYAD, Abdelmalek. A imigração ou os paradoxos da alteridade. São Paulo: Editora da Universidade de São Paulo, 1998.

SIMON, Sherry. Traverser Montréal: une histoire culturelle par la traduction. Montréal: Fides, 2008.

TREMBLAY, Michel. Un ange cornu avec des ailes de tôle. Leméac/ Actes Sud, 1996.

2007.

. La traversée du continent. Montréal: Leméac/Actes Sud,

VERNANT, Jean-Pierre. A travessia das fronteiras: entre mito e política II. São Paulo: EDUSP, 2009. 